\title{
Expressed emotion in fibromyalgia: Contribution of spouses' attitude and patients' perception to clinical presentation of fibromyalgia
}

\section{Fibromyalji”de duygu ifadesi:: fibromyalji kliniğine, eşlerin tutumunun ve hastanın algısının katkısı}

Emrullah Hayta ${ }^{1}$, Derya Gülliz Mert ${ }^{2}$, Esra Aydınkal Semiz ${ }^{3}$, Sami Hizmetlii ${ }^{1}$

'Department of Physical Medicine and Rehabilitation, Cumhuriyet University Faculty of Medicine, 58140 Sivas, Turkey
${ }^{2}$ Department of Psychiatry, Cumhuriyet University Faculty of Medicine, 58140 Sivas, Turkey
${ }^{3}$ Department of Physical Medicine and Rehabilitation, Halil Sivgin Cubuk State Hospital, 58100 Ankara, Turkey
Corresponding author: Emrullah Hayta, Department of Physical Medicine and Rehabilitation, Cumhuriyet University
Faculty of Medicine, 58140 Sivas, Turkey
E-mail: dremay @gmail.com
Received/Accepted: November 10, 2016/ November 16, 2016
Conflict of interest: There is not a conflict of interest.

\section{SUMMARY}

Objective: Psychopathological symptoms presented by fibromyalgia patients include introversion, inability to reflect emotional needs, lack self-esteem, and inefficiency in social relationships. There are measures to assess the relationship of the expressed emotion of patients and spouses with severity of fibromyalgia syndrome (FS). The aim of this study to assess the effect of expressed emotion of patient (LEE) and her spouse (EE) on the severity of FS in women.

Method: 123 FS patients and 105 healthy controls enrolled for the study. In the study, fibromyalgia impact questionnaire (FIQ), Montgomery-Asberg Depression Rating Scale (MADRAS), and level of expressed emotion (LEE) and expressed emotion (EE) were recorded.

Results: LEE in FS was significantly higher than that in healthy controls [15 (2-56) vs. 11 (3-38); $\mathrm{p}<0.05]$. The EE in FS was significantly higher than that in healthy controls (14.2 $\pm 4.3 \mathrm{vs} .12 .4 \pm 4.2$; $\mathrm{p}<0.05)$. The FIQ score had mild correlations with LEE and EE, place of residence, and family history of FS ( $r=0241, r=0183,0.214$, and 0.203; respectively) but not with education status, family type, MADRAS score, number of tender points, and duration of FS ( $p>0.05)$. After linear hierarchical regression analysis was done to determine to the interaction of EE on the relationship of LEE and FIQ scores, there was no statically significant interaction of EE on the relationship of LEE and FIQ scores ( $\mathrm{p}>0.05)$.

Conclusions: The findings of this study support the value of assessment of EE from the perspective of patients and their spouses during the management of FS. To improve the psychological function of FS patients, in clinical practice, considering the role of spouses may provide an important advantage and increase the success of management of FS.

Keywords: Fibromyalgia, Expressed emotion, Contribution of spouses 
ÖZET

Amaç: Fibromyalji'li hastaların (FS) ortaya koydukları psikosomatik semptomlar; içe kapanıklık, duygusal ihtiyaçlarını yansıtmada yetersizlik, öz güven eksikliği ve sosyal ilişkilerde yetersizliği içermektedir. Hastalar ve eşlerinin duygu ifadelerinin arasındaki ilişkiyi FS'nin şiddetine göre değerlendiren ölçekler bulunmaktadır. Bu çalışmanın amacı FS'li hastanın duygu durumunun ve onun eşinin tutumunun hastalığın kliniği üzerine etkisini değerlendirmektir.

Yöntem: çalışmaya 123 hasta ve 105 sağlıklı kontrol dahil edilmiştir. Bu çalışmada, fibromyalji etki anketi (FIQ), Montgomery-Asberg Depresyon Ölçeği (MADRAS), ve duygu ifadesi seviyesi (LEE) ve duygu ifadesi (EE) kaydedilmiştir.

Bulgular: FS'deki LEE sağl1klı kontrollere kıyasla oldukça yüksekti [15 (2-56) vs. 11 (3-38); $\mathrm{p}<0.05]$. FS'deki EE sağlıklı kontrollere kiyasla oldukça yüksekti (14.2 \pm 4.3 vs. $12.4 \pm 4.2 ; p<0.05)$. FIQ skoru LEE ve EE ile yaşanılan yer ve FS aile öyküsüyle 1lımlı bir korelasyon göstermekteydi ( $\mathrm{r}=0241, \mathrm{r}=0183,0.214$, ve 0.203 ; sirayla); fakat bu korelasyon eğitim durumu, aile tipi, MADRAS skoru, hassas noktaların sayısı ve FS'in süresi ( $>0.05$ ) arasında bulunmamaktaydı. EE'nin LEE ve FIQ skoru üzerindeki etkisini belirlemek için Lineer regresyon analizi yapıldı ve herhangi bir etkisi olmadığı bulundu ( $>>0.05)$.

Sonuç: bu çalışmanın bulguları, FS'nin tedavisi esnasında hastalar ve onların eşleri açısından EE’nin ölçme açısından değerli olduğunu desteklemektedir. FS hastalarında psikolojik fonksiyonları iyileştirmek için, klinik uygulamada, eşlerin rolünü değerlendirmeye almak önemli bir avantajdır ve FS'nin tedavi başarısını arttırır.

Anahtar sözcükler: Fibromyalji, Duygu ifadesi, Eşin katkısı

\section{INTRODUCTION}

Fibromyalgia syndrome (FS) is a chronic condition of widespread pain accompanied by symptoms such as morning stiffness, depression, and fatigue, sleep disturbance, and impaired mental functioning ${ }^{1}$. Since the etiology of this syndrome is not clarified, clinicians and researchers theorize that it might stem from various factors, including stress, medical illness, pain conditions, and certain disturbances in terms of neurotransmitter and neuroendocrine ${ }^{2,3}$. The perception of disease-related factors, that is, disease severity, functional ability, and pain threshold and tolerance might be detrimentally affected by high levels of stress and psychiatric symptoms ${ }^{4-7}$.

Recent studies have focused on the potential contributors on the development of FS ${ }^{8}$. The personality factors such as lower levels of extroversion and positive affect are among the significant elements affecting the clinical development of FS ${ }^{9}$. There may be a high level of harm avoidance trait in FS ${ }^{10}$. Generally, patients with FS tend to display a sociotropic personality style exhibited by patients with major depressive disorder. Other studies have clearly indicated that cognitive performance of FS patients cannot be evaluated independent from personality traits ${ }^{8,11}$. It has been known that mood disorders play a significant role in the onset and development of the disease and that FS cases have characteristics that are generally introversion, inability to reflect emotional needs, lack self-esteem, and inefficiency in social relationships ${ }^{12,13}$. There are measures that can be used to evaluate the emotional relation between the patient and their spouse, and to benefit from some features of this relation ${ }^{14,15}$. Expressed emotion (EE) which is mainly composed of criticism, hostility and emotional overinvolvement, is a measure used in the assessment of the emotional atmosphere of the home environment ${ }^{16}$. In the research on EE, it has been clearly indicated that the course of many psychiatric disorders, ranging from depression, anxiety, schizophrenia, to posttraumatic stress disorder and eating disorders is detrimentally affected by daily interactions of psychiatric patients with a relative or partner, which emphasize criticism, hostility, and/or emotional over involvement ${ }^{17}$. However, if $\mathrm{EE}$ is dealt with as a measure of 
converse social support, its clinical uses are even broader that cannot be restricted to psychiatric disorders alone. In this context, potentially predictive value of EE for the course of several medical conditions such as even asthma, diabetes and epilepsy were reviewed ${ }^{18}$. First, as mentioned above, EE is a more general predictor of poor outcome across a broad range of conditions. More importantly, $\mathrm{EE}$ is a construct, which is effectively modifiable. Some experimental studies on family-based treatment of several diseases encouragingly revealed that the decrease in family EE levels also decreased the severity of the disease and patients' relapse rates. When evaluated from clinical perspective, the findings of this body of research are promising in terms of indicating that EE can be effectively used in the clinical treatment of diseases related to psychiatric disorders such as FS ${ }^{19,20,21}$.

Although the pain and somatic symptoms appear related to psychological states in FS, and recent studies suggest that one of the possible lines of research in FS should focus on the interrelationships between somatic symptoms and personality, this possible relationship has not received much empirical attention. We think that expressed emotion as measured from patient and relative sides can contribute the knowledge about the influence of expressed emotion on the clinical course of FS. In the pertinent literature, there was no study investigating the interaction of clinical severity of FS and perception of patients about their disease under the influence of behavioral changes of their spouses during living together with a person with FS. The aim of this study to assess the effect of expressed emotion of patient and her spouse on the severity of FS in women.

\section{MATERIAL AND METHOD}

\section{Case selection}

The approval of Human Ethics Committee of our University and informed consent were obtained for all the participants. During the study period, 140 consecutive patients who clinically meet ACR's FS diagnosis criteria [22] and 140 spouses of them, and 105 female volunteers and 105 spouses of these volunteers were identified as suitable for the study. The sample group with FS were selected particularly from the married people in order to evaluate the attitude of their partner. Some subjects were excluded from the study because they were pregnant, had sleep disturbance, a neurological disease, or a current diagnosis of a psychiatric disorder (e.g., current schizophrenia, major depression with suicidal ideation, or substance abuse) and because their partner did not follow the questionnaire sessions. In the study, age, education, place of residence, family type, duration of FS, number of tender point, and fibromyalgia impact questionnaire (FIQ), Montgomery-Asberg Depression Rating Scale (MADRS), and LEE scores of both the FS and control groups were recorded.

Fibromyalgia impact questionnaire

The FIQ [10] comprises of 10 items the first which includes 11 subcategories investigating the ability to conduct large muscle tasks. The rating of each question was rated on a 4-point (0 to 3) Likert-type scale. In the items 2 and 3 , the patients were asked to report about the number of days in which they are fed up to conducting their normal daily tasks and they failed to perform these tasks due to FS symptoms. Items from 4 to 10 were designed as horizontal linear scales having 10 increments through which work difficulty, pain, fatigue, morning tiredness, stiffness, anxiety, and depression were rated. When the rating was concluded, the emerging scores were normalized: any of the items can possibly have maximum score of 10 , and the total score can be maximum 100. The higher scores are in the questionnaire, the greater the functional impairment. In most clinical trials on FS, the FIQ is one of the tools primarily recommended to measure the primary efficacy end point. The psychometric characteristics of Turkish translation are not very different from the original English version ${ }^{23}$. 


\section{Montgomery-Asberg Depression Rating Scale (MADRS)}

Montgomery and Åsberg Depression Rating Scale (MADRS), the quantification of depressive symptoms, were conducted in the follow-up sessions 24. 65 original items from the Comprehensive Psychopathological Rating Scale were used to develop the MADRS. With putting little focus on somatic symptoms, this scale measures a variety of items including apparent sadness, reported sadness, inner tension, reduced sleep, reduced appetite, concentration difficulties, lassitude, and ability to feel pessimistic thoughts and suicidal thoughts. This scale which is rated by the observers has the rating range between 0 and 60 with high scores indicating accumulation of depressive symptoms. The items included in MADRS have all been validated through studies conducted on in Turkish population ${ }^{25}$.

\section{Level of Expressed Emotion (LEE)}

This scale is a self-evaluation tool developed by Cole and Kazarian (14) in order to understand the emotional state between the patient and the individual significant for the patient and to evaluate some characteristics of the relation. The LEE is a 60-item questionnaire, specifically designed to measure the perceived $\mathrm{EE}$ of the most influential person in the participant's life during the last three months. The four subscales of the LEE are Intrusiveness, Negative Attitude, Tolerance/expectation and Emotional Response. Higher scores indicate higher levels of EE. The original 60-item scale with a 4-point Likert response (not true; mostly untrue; mostly true; true) was employed in this study. It includes some subscales with 15 items, such as intrusiveness (I), emotional response (E), attitude toward illness (A), tolerance/expectation (T). Subscale points range between 0 and 15 , and the total points range between 0 and 60 . The adaptation of the scale into Turkish and its validity and reliability studies were conducted by Berksun ${ }^{26}$.

\section{Expressed Emotion (EE)}

Expressed Emotion, which bases on the perception of the relatives of the patients related to the interpersonal relations, have been developed to measure expressed emotion in order to define and evaluate the emotional tone accompanying the interaction in the relations from the perspective of relatives. There is no Turkish version of original EE including 60 items. EE from the perspective of relatives was measured with EE that was developed as including 41 items in Turkish by Berksun and its validity and reliability was published as a dissertation thesis ${ }^{26}$. In this, there are questions considering how the relatives of the patients perceive both the patient and themselves and $\mathrm{EE}$ is measured in parallel with the written answers to the items. Out of 41 items, 29 items measure criticism and hostility and 12 items measure emotional over involvement. "I do not believe that she is ill" and "Her existence makes me mad" might be example items of criticism and hostility and "I coddle her" and "I worry that something might happen to her" might be example items for emotional over involvement. EE levels increase as the points in the increase which are replied in the form of 'true' or 'false' and which are graded between 0 and 1 . Total point ranges from 0 to 41 . The fact that Turkish social and cultural characteristics have been taken into consideration when the items were prepared is among the strong points of the scale developed by Berksun.

\section{Statistical Analysis}

Data were presented as mean $\pm \mathrm{SD}$, median (min-max), percentage as appropriate. All data were analyzed using IBM SPSS ver. 21 (IBM Co., Armonk, NY, USA). Normality was tested using one-sample Kolmogorov-Smirnov test. The age was compared between the FS group and healthy controls with t test. The scores and sub-scores of LEE were compared with Mann-Whitney test. The score EE were compared with t test. Chisquare test was used for analyses of the ratios of education, place of residence and family type of the study groups. The 
relationship of FIQ score with clinical parameters including the scores of LEE and EE, place of residence, and family history of FS, education status, family type, MADRAS score, number of tender points, and duration of FS were analyzed with correlation and chi-square tests. The relationship of scores of LEE and EE with clinical parameters including FIQ score, place of residence, and family history of FS, education status, family type, MADRAS score, number of tender points, and duration of FS were analyzed with correlation and chi-square tests. Linear hierarchical regression analysis was used to determine to interaction of
EE on the relationship of LEE and FIQ scores. A $p$ value of less than 0.05 was accepted statistically significant.

\section{RESULTS}

In the FS group and healthy controls, 17 patients and 15 healthy controls, respectively, did not complete the study. Analyses of data were performed with 123 FS patients and 105 healthy controls. Table 1 presents the selected demographic and clinical data of FS group and healthy controls.

Table 1. Selected demographic and clinical data of study population.

\begin{tabular}{|l|l|l|}
\hline & Fibromyalgia syndrome $(\mathrm{n}=123)$ & Healthy controls $(\mathrm{n}=105)$ \\
\hline Age, $\mathrm{y}$ & $41.8 \pm 9.0$ & $37.2 \pm 10.8$ \\
\hline $\begin{array}{l}\text { Education status } \\
\text { Up to high school }\end{array}$ & $107(86.9 \%)$ & $98(93.3 \%)$ \\
University & $16(13.1 \%)$ & $7(6.7 \%)$ \\
\hline $\begin{array}{l}\text { Place of residency } \\
\text { Rural }\end{array}$ & $31(25.2 \%)$ & $26(24.8 \%)$ \\
Urban & $92(74.8 \%)$ & $79(75.2 \%)$ \\
\hline Family type & $101(82.1 \%)$ & $90(85.7 \%)$ \\
Nuclear & $22(17.9 \%)$ & $15(14.3 \%)$ \\
Joint & $2(1-3)$ & \\
\hline Duration of FS,y & $12.8 \pm 3.2$ & \\
\hline Number of tender point & $67.3 \pm 13.9$ & $3.6 \pm 2.7$ \\
\hline FIQ score & $12.9 \pm 5.2^{\mathrm{a}}$ & \\
\hline MADRS score & & $3(0-15)$ \\
\hline LEE & $4(0-15)^{\mathrm{b}}$ & $5(1-10)$ \\
Emotional & $5(0-15)$ & $2(0-8)$ \\
Intrusiveness & $3(0-15)$ & $2(0-10)$ \\
Attitude & $3(0-15)^{\mathrm{c}}$ & \\
Tolerance & & \\
\hline $\begin{array}{l}\text { Data were presented as mean } \pm \text { SD or median (min-max). } \\
\text { a,b,cP }<0.05 \text { vs. healthy controls. }\end{array}$ &
\end{tabular}

Age, education, place of residence, family type, intrusiveness and attitude of study groups were found similar ( $>>0.05)$. The median score of LEE in the FS patients was significantly higher than that in the healthy controls [15 (2-56) vs. 11 (3-38); $\mathrm{p}<0.05]$ (Figure 1). The median sub-scores of LEE including emotional and tolerance in FS group was significantly higher than that of the healthy controls $(p<0.05)$. The median score of EE in the FS patients was significantly higher than that in the healthy controls $(14.2 \pm 4.3$ vs. $12.4 \pm 4.2$; $\mathrm{p}<0.05$ ) (Figure 1). The other sub-scores were not significantly different within the study group $(\mathrm{P}>0.05)$. 


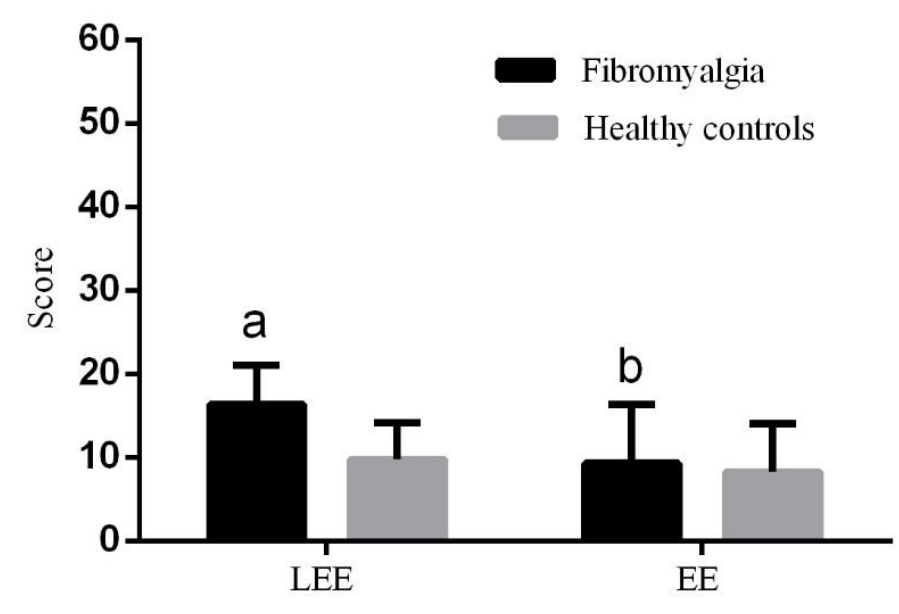

Figure 1. Scores of LEE and EE in patients with FS and healthy subjects.

There was a significant but mild positive correlation between the score of LEE with the age and family type $(\mathrm{r}=0.2$ and $\mathrm{r}=0.3$, respectively; $\mathrm{p}<0.05$ ). There was a significant but mild positive correlation between the score of EE with the FIQ score and score of LEE ( $\mathrm{r}=0.183$ and $r=0.260$, respectively; $p<0.05)$. the FIQ score presented significant mild correlations with the scores of LEE and EE, place of residence, and family history of FS ( $r=0241, r=0183,0.214$, and 0.203; respectively) but not with education status, family type, MADRAS score, number of tender points, and duration of FS $(p>0.05)$. When linear hierarchical regression analysis is conducted to determine to the interaction of EE on the relationship of LEE and FIQ scores, there was no statically significant interaction of EE on the relationship of LEE and FIQ scores $(\mathrm{p}>0.05)$.

\section{DISCUSSION}

In this cross-sectional study, we evaluated the impact of EE measured in the perspective of patients and their spouses on the clinical presentation of FS and to knowledge of the researcher, the present study is the first one in this respect. The FS patients and healthy controls were found comparable with regard to the clinical features. The FS patients had higher EE compared to healthy controls. Overall, the severity of FS was moderate in FS patients who had mild degree of depression. Among the sub-scores of LEE, emotional and tolerance sub-scores were higher in the FS patients compared to the healthy controls. The age and family type revealed mild correlation with the score of LEE and they affected the score of LEE as independent factors in the FS patients. Overall, according to results of the study, the unfavorable behavior of spouse regarding the lifestyle changes related to the symptoms of FS worsens the perception of patient about their disease and the long-term burden of FS. We found a mild interaction of attitude of spouse on the severity of FS.

The interaction of psychological status and FS is complex. Psychological disorders can be present as a causative factor. They can also develop 
consequently during the long-term course of FS ${ }^{28}$. As in many chronic conditions, psychological stress is added to the clinical presentation of FS and alters its clinical presentation in long-term ${ }^{29}$. In FS, the burden of pain and disability caused by the disorder, and possible symptoms of any primary psychiatric abnormality may worsen the quality of life in FS patients. In the current study, the focus of research was the contribution of spouses' attitude on the psychological stress in FS patients. In the related literature, there was no study on the role of attitude of spouse on the psychological stress of FS patients, investigating this condition with the LEE and EE. Since there is controversy over the extent to which psychiatric illnesses such as depression is a part of this disorder, in the current study, FS patients with none to mild degree of depression were included to minimize the effect of contribution of psychological stress of FS patients. Attitude of patients as well as their spouses about FS is one of the important predictors of treatment success. As in other chronic disorders, if FS patients understand that contribution of spouses' attitude to the management of disorder, they can improve their quality of life as a family and the compliance with management plan ${ }^{30}$.

Mounting body of evidence in literature advocates EE as a means of evaluation of the family's perspective and attitude towards the condition of the patient, and argues that the relatives' attitude is a significant factor influencing the course of a chronic disease both positively and negatively ${ }^{31}$. The clinical manifestation of fibromyalgia can considerably be affected by psychological, behavioral, and social issues which are on the agenda of the patient, but the partner, particularly the spouse is of a relative influence on the course of the disorder, thus on the life of a patient with FS. The disability to which FS patient is exposed is likely to have a significant correlation with the partner's sense of burden, who acts as a contributing factor to the severity of the symptoms and whose reactions to the patient and the symptoms of the disorder can be supportive, overprotective, or discouraging of activity ${ }^{32,33}$. This may trigger a mechanism similar to the one in chain reaction in which patient disability deteriorates partner perception and behavior, which naturally has a devastating effect on patient's life and functioning. The burden the caregiver feels on the face of the symptoms has a positive correlation to the severity of disability ${ }^{34}$. Similarly, supportive behaviors of the partner who, in most situations, also acts as the caregiver directly influence the functional disability of the patient ${ }^{35,36}$. Partner's over-supportive and protective behaviors might result in higher levels of disability 33, 37. Our results support that the EE is related with the severity of FS. As the EE increases, the severity of FS increases relatively.

Söderberg ${ }^{38}$ evaluated the experiences of spouses related to the emotional impact resulted from the illness of the patients with FS. The author interviewed with husbands of FS patients to assess the emotional status in their relationship and its effect on their lifestyle, and concluded that the patient and her husband together were influenced during the course of FS. Dogan et al. ${ }^{39}$ assessed the impact of living with a patient with FS on their general health status, psychological status and quality of life. They suggested that those health parameters did not impaired in the relatives of patients with FS. Although they noted that the psychological status of relatives/spouses of study population was comparable with healthy controls, they did not include the EE in that study.

Higher symptom levels in FS notably mental distress were tend to be related to negative emotions and any decrease in symptom levels were tend to be related to positive emotions. According to the dynamic model of affect, during the episodes of stress and pain, the experience of negative affect can be offset by the presence of positive affect ${ }^{40}$. Although our study focusing on the interpersonal interactions have not explored strong evidence pertaining to the aforementioned hypothesis, studies 
utilizing within-subject analyses have supported such a buffering effect ${ }^{41}$. In fact, in the present study, though a high frequency disturbance in emotional experiencing in fibromyalgia was registered, relationships with pain and fatigue were found to be weak. As a result, despite the relative independence between items such as pain and fatigue, it might seem difficult to improve FS symptoms by improving affective functioning; the major disturbances in emotional domain is worthy of due attention. Despite the fact that emotional factors and symptoms are generally interrelated, some relationships between emotional factors and symptoms might be limited to some subsets of patients. For instance, the dynamic model of affect proposes that negative emotions can have a relation to pain (and perhaps fatigue) only for patients experiencing positive affect in low levels ${ }^{42}$.

This study has limitation related to duration of diseases since the patients with FS had less than three years of duration of diseases; however, all of their diseases were at least moderate degree of severity. We think that the influence of living with FS on patients and their spouses will be adequate to affect the EE. The findings of this study support the value of assessment of $\mathrm{EE}$ in the perspective of patients and their spouses during the management of FS. To improve the psychological function of FS patients, in clinical practice, considering the role of spouses may provide an important advantage and increase the success of management of FS.

\section{REFERENCES}

1. Wolfe F, Ross, K, Anderson J, Russell IJ, Hebert L.The prevalence and characteristics of fibromyalgia in the general population. Arthritis Rheum 1995; 38: 19-28.

2. Di Tella M, Castelli L.Alexithymia and fibromyalgia: clinical evidence Front Psychol. 2013; 4: 909.

3. Mease P. Fibromyalgia syndrome: review of clinical presentation, pathogenesis, outcome measures, and treatment. J. Rheumatol 2005; 75: 6-21.
4. Hawley DJ, Wolfe F, Cathey MA. Pain, functional disability, and psychological status: a 12-month study of severity in fibromyalgia. J. Rheumatol 1998; 15: 1551-6.

5. Epstein SA, Williams DA, Osbeck L, Clauw D. Effect of psychological factors on pain perception in fibromyalgia (abstract). Psychosomatics 1995; 36: 192.

6. Ledingham J, Doherty S, Doherty M. Primary fibromyalgia syndrome: an outcome study. Br J Rheumatol 1993; 32: $139-42$

7. McBeth J, Chiu YH, Silman AJ, Ray D, Morriss R, Dickens C, et al. Hypothalamic-pituitary-adrenal stress axis function and the relationship with chronic widespread pain and its antecedents. Arthritis Res Ther 2005; 7: R992-R1000.

8. Becerra-García JA, Robles Jurado MJ. Behavioral approach system activity and self-reported somatic symptoms in fibromyalgia: an exploratory study. Int J Rheum Dis 2014; 17: 89-92.

9. Zautra AJ, Fasman R, Reich JW, Harakas P, Johnson LM, Olmsted ME, et al. Fibromyalgia: evidence for deficits in positive affect regulation. Psychosom Med 2005; 67: 147-55.

10. Glazer Y, Buskila D, Cohen H, Ebstein RP, Neumann L. Differences in the personality profile of fibromyalgia patients and their relatives with and without fibromyalgia. Clin Exp Rheumatol 2010; 28: 27-32.

11. Nordahl HM, Stiles TC. Personality styles in patients with fibromyalgia, major depression and healthy controls. Ann Gen Psychiatry 2007; 6: 9.

12. Geisser ME, Casey KL, Brucksch CB, Ribbens CM, Appleton BB, Crofford LJ. Perception of noxious and innocuous heat stimulation among healthy women and women with fibromyalgia: associate on with mood, somatic focus, and catastrophizing. Pain 2003; 102: 243-50.

13. van Middendorp H, Lumley MA, Jacobs JW, van Doornen LJ, Bijlsma, JW, Geenen R. Emotions and emotional approach and avoidance strategies in fibromyalgia. J Psychosom Res 2008; 64: $159-67$. 
14. Cole JD, Kazarian SS.The level of Expressed Motion scale: a new measure of expressed emotion. Journal of Clinical Psychology 1998; 44: 392-7.

15. Startup M. Confirmatory factor analysis of the level of expressed emotion (LEE) scale. British Journal of Medical Psychology 1999; 72: 421-4.

16. Barrowclough $\mathrm{C}$, Ward J, Wearden A, Gregg L. Expressed emotion and attributions in relatives of schizophrenia patients with and without substance misuse. Soc Psychiatry Psychiatr Epidemiol 2005; 40: 884-91.

17. Butzlaff RL, Hooley JM. Expressed emotion and psychiatric relapse: a metaanalysis 1998; 55: 547-52.

18. Wearden AJ, Tarrier N, Barrowclough C, Zastowny TR, Rahill AA. A review of expressed emotion research in health care 2000; 20: 633-66.

19. Hooley JM. Expressed emotion and relapse of psychopathology. Annu Rev Clin Psychol 2007; 3: 329-52.

20. Watts M. High expressed emotion: precipitating relapse in substance misuse disorders. Br J Nurs 2007; 16: 1396-8.

21. Broderick JE, Junghaenel DU, Schwartz JE. Written emotional expression produces health benefits in fibromyalgia patients. Psychosom Med 2005; 67: 32634.

22. Wolfe F, Smythe H, Yunus M, Bennett $\mathrm{R}$, Bombardier C, GoldenbergD, et al. The American College of Rheumatology 1990 criteria for the classification of fibromyalgia: report of the multicenter criteria committee. Artritis Rheum 1990; 33: 160-72.

23. Sarmer S, Ergin S, Yavuzer G. The validity and reliability of the Turkish version of the Fibromyalgia Impact Questionnaire. Rheumatol Int 2000; 20: 9-12.

24. Montgomery SA, Åsberg M. New Depression Scale Designed to be Sensitive to Change. Brit J Psychiat 1979; 134: 382-9.

25. Ozer SK, Demir B, Tugal O, Kabakcı E, Yazici MK. Montgomery-Asberg Depression Rating Scale: Inter-rater reliability and validity study (Turkish). Turk Psikiyatri Derg 2001; 12: 185-94.
26. Berksun OE. Şizofrenide aile faktoru: expressed emotion (EE) olcek gelistirme ve uyarlama denemesi. (Family factor in schizophrenia: developing and adapting an expressed emotion scale.) Ankara University, Turkey [Unpublished Dissertation Thesis], 1992.

27. Eskin M. Reliabilty of Turkish version of the perceived social support from friends and family scales, scale for interpersonal behaviour and suicide probability scale. $\mathbf{J}$ Clin Psychol 1993; 49: 515-22.

28. Fuller-Thomson E, Nimigon-Young J, Brennenstuhl S. Individuals with fibromyalgia and depression: findings from a nationally representative Canadian survey. Rheumatol Int 2012; 32: 853-62.

29. Malin K, Littlejohn GO. Stress modulates key psychological processes and characteristic symptoms in females with fibromyalgia. Clin Exp Rheumatol 2013; 31: 64-71.

30. Consoli G, Marazziti D, Ciapparelli A, Bazzichi L, Massimetti G, Giacomelli C, et al. The impact of mood, anxiety, and sleep disorders on fibromyalgia. Compr Psychiatry 2012; 53: 962-7.

31. Devaramane V1, Pai NB, Vella SL.The effect of a brief family intervention on primary carer's functioning and their schizophrenic relatives levels of psychopathology in India. Asian J Psychiatr 2011; 4: 183-7.

32. Keers JC, Hagedoorn M, Buunk BP. Depressive feelings and somatic complaints of patients with fibromyalgia: the role of partners' active involvement, overprotectiveness, and protective buffering. Gedrag Gezond 2003; 31: 1929.

33. Reich JW, Olmsted ME, van Puymbroeck CM. Illness uncertainty, partner caregiver burden and support, and relationship satisfaction in fibromyalgia and osteoarthritis patients. Arthritis Rheum 2006; 55: 86-93.

34. Vitaliano PP, Zhang J, Scanlan JM. Is caregiving hazardous to one's physical health? A meta-analysis. Psychol Bull 2003; 129: 946-72.

35. Martire LM, Stephens MA, Druley JA, Wojno WC. Negative reactions to received spousal care: predictors and 
consequences of miscarried support. Health Psychol 2002; 21: 167-76.

36. Vitaliano PP, Russo J, Young HM, Teri L, Maiuro RD. Predictors of burden in spouse caregivers of individuals with Alzheimer's disease. Psychol Aging 1991; 6: 392-402.

37. Faison KI, Faria SH, Frank D. Caregivers of chronically ill elderly: perceived burden. J Community Health Nurs 1999; 16: 243-53.

38. Söderberg S, Strand M, Haapala M, Lundman B. Living with a woman with fibromyalgia from the perspective of the husband. J Adv Nurs 2003; 42: 143-50.

39. Dogan SK, Aytur YK, Atbasoglu C. Assessment of the relatives or spouses cohabiting with the fibromyalgia patients: is there a link regarding fibromyalgia symptoms, quality of life, general health and psychologic status? Rheumatol Int 2011; 31: 1137-42.

40. Davis MC, Zautra AJ, Smith BW. Chronic pain, stress, and the dynamics of affective differentiation. J Pers 2004; 72 : 1133-59.

41. Zautra AJ, Johnson LM, Davis MC. Positive affect as a source of resilience for women in chronic pain. J Consult Clin Psychol 2005; 73: 212-20.

42. Strand EB, Zautra AJ, Thoresen M, Ødegård S, Uhlig T, Finset A. Positive affect as a factor of resilience in the painnegative affect relationship in patients with rheumatoid arthritis. J Psychosom Res 2006; 60: 477-84. 